\title{
KEWENANGAN NOTARIS NON PPAT DALAM PEMBUATAN AKTA YANG BERKAITAN DENGAN PERTANAHAN
}

\author{
Oleh : \\ Rizki Kurniawan ${ }^{*}$, Siti Nurcholifah ${ }^{* *}$ \\ *Fakultas Hukum, Universitas Gresik \\ Email : rizkikurniawansgmh@gmail.com \\ ${ }^{* * *}$ Fakultas Hukum Universitas Gresik \\ Email : cholifah630@gmail.com
}

\begin{abstract}
ABSTRAK
Ketentuan Pasal 15 ayat (2) huruf f Undang-Undang Jabatan Notaris yang menyatakan bahwa Notaris berwenang untuk membuat akta yang berkaitan dengan pertanahan membuat terjadi adanya suatu konflik norma dalam kewenangan pembuatan akta pertanahan. Hal tersebut memunculkan banyak macam penafsiran dan pro kontra. Penelitian ini menganalisis tentang kewenangan Notaris yang tidak menjabat sebagai PPAT dalam membuat akta pertanahan dan pelaksanaan kewenangan Notaris yang tidak menjabat sebagai PPAT terhadap Pasal 15 ayat (2) huruf f UUJN. Kemudian untuk menjawab pertanyaan tersebut penulis menggunakan metode penelitian hukum normatif (Normative Legal Research), yaitu suatu penelitian yang dilakukan dengan cara mengkaji peraturan perundangundangan yang berlaku atau diterapkan terhadap suatu permasalahan tertentu. Hasil penelitian menunjukkan bahwa Notaris dapat membuat akta yang berhubungan dengan pertanahan, akan tetapi dalam kewenangannya tersebut dibatasi oleh peraturan perundang-undangan yang mengatur mengenai PPAT. Keberadaan Pasal 15 ayat (2) huruf $\mathrm{f}$ UUJN tidak mengurangi atau menghilangkan kewenangan PPAT dalam pembuatan akta pertanahan yang sebelumnya telah menjadi kewenangan PPAT.
\end{abstract}

Kata Kunci : Notaris, Kewenangan, Akta Pertanahan.

\section{A. PENDAHULUAN}

Notaris selaku pejabat yang berwenang membuat akta atau alat bukti tertulis otentik di bidang perekonomian masyarakat khususnya. Disamping kebutuhan dalam tatanan kehidupan bermasyaratkat terkait dengan hubungan hukum keperdataan perseorangan dan keluarga yang berhubungan dengan harta benda, hak dan mewajiban berupa hubungan perkawian, harta perkawinan, wasiat, dan harta warisan sesuai dengan KUHPerdata menjadikan semua akta yang dibuat oleh dan di hadapan notaris tersebut selain menyangkut kepastian hukum sebagai alat bukti tertulis tentang tempat, jam, tanggal, bulan, tahun, isi/materi, waktu yang berlaku, saksi, obyek, subyek dan penandatanganan juga memastikan tentang kadaluarsa (verjaring). ${ }^{1}$

Terkait dengan kewenangan Notaris, yaitU sebagaimana disebutkan dalam Pasal 15 ayat (1) Undang-Undang Nomor 30 Tahun 2004 Tentang Jabatan Notaris sebagaimana telah diubah dengan Undang-Undang Nomor 2 Tahun 2014 Tentang Perubahan Atas Undang-Undang Nomor 30 Tahun 2004 Tentang Jabatan Notaris (selanjutnya disingkat UUJN), disebutkan: "Notaris berwenang membuat Akta autentik mengenai semua perbuatan, perjanjian, dan penetapan yang diharuskan oleh peraturan perundang-undangan dan/atau yang dikehendaki oleh yang berkepentingan untuk dinyatakan dalam Akta autentik, menjamin kepastian tanggal 
pembuatan Akta, memberikan grosse, salinan dan kutipan Akta, semuanya itu sepanjang pembuatan akta itu tidak juga ditugaskan atau dikecualikan kepada pejabat lain atau orang lain yang ditetapkan oleh undang-undang"

Akta otentik menurut Pasal 1868 KUHPerdata merupakan akta yang dibuat oleh pejabat yang berwenang yang bentuknya ditentukan oleh undang-undang. Berdasarkan kewenangan itu maka Notaris dianggap berwenang langsung untuk membuat akta yang berkaitan dengan pertanahan yang merupakan juga akta otentik tanpa harus menjadi Pejabat Pembuat Akta Tanah (PPAT). Hal ini pun didukung oleh Undang-Undang Jabatan Notaris, yakni Pasal 15 ayat (2) huruf f UUJN yang menyatakan bahwa Notaris berwenang untuk membuat akta yang berkaitan dengan pertanahan. $^{2}$

Kewenangan yang diberikan kepada Notaris dijelaskan dan diuraikan pada Pasal 15 ayat (2) UUJN. Akan tetapi dari beberapa uraian kewenangan tersebut, ada yang menjadi suatu permasalahan dikalangan Notaris dan pihak yang merasa dirugikan. Lahirnya Pasal 15 ayat (2) huruf f UUJN mengenai kewenangan Notaris membuat akta yang berkaitan dengan pertanahan menimbulkan kekaburan makna pada ayat tersebut. Selama ini pembuatan akta yang berkaitan dengan pertanahan menjadi wewenang PPAT. PPAT diberikan mandat oleh Peraturan Pemerintah membuat akta otentik yang berhubungan dengan tanah. Dalam ketentuan Pasal 19 Nomor 5 Tahun 1960 Undang-Undang Pokok Agraria (selanjutnya di singkat UUPA) yang mengamanatkan tentang pendaftaran tanah menurut ketentuan-ketentuan yang diatur dalam Peraturan Pemerintah. Selanjutnya PPAT ini diatur pada Pasal 1 Peraturan Pemerintah Nomor 24 Tahun 2016 yang menyebutkan bahwa PPAT adalah Pejabat Umum yang diberi kewenangan membuat akta-akta otentik mengenai perbuatan hukum tertentu mengenai Hak Atas tanah atau Hak Milik Atas Satuan Rumah Susun.

Menurut Boedi Harsono Pendaftaran Tanah adalah rangkaian kegiatan yang dilakukan

${ }^{2}$ Habib Adjie, Hukum Notaris Indonesia: Tafsir Tematik Terhadap UU No. 30 Tahun 2004 Tentang Jabatan Notaris, Cetakan Ke-6, Refika Aditama, Bandung, 2010, h. 11.

3 Boedi Harsono, Hukum Agraria Indonesia, Sejarah Pembentukan UUPA, Isi, dan Pelaksanaannya,
Pemerintah/Negara secara terus menerus dan teratur berupa pengumpulan keterangan atau data tertentu mengenai tanah-tanah tertentu yang ada di wilayah-wilayah tertentu, pengolahan, penyimpanan dan penyajiannya bagi kepentingan rakyat, dalam rangka memberikan jaminan kepastian hukum di bidang pertanahan, termasuk penerbitan tanda bukti dan pemeliharaannya. ${ }^{3}$

$$
\text { Pada permasalahan kewenangan }
$$

membuat akta yang berkaitan dengan pertanahan, maka haruslah dipahami dahulu tentang masalah tanah dan hak atas tanah. Pengertian tanah dalam arti yuridis adalah permukaan bumi sebagaimana disebutkan dalam Pasal 4 ayat (1) UndangUndang Nomor 5 Tahun 1960 UUPA, sedangkan hak atas tanah adalah hak atas sebagian tertentu permukaan bumi, yang berbatas, berdimensi dua dengan ukuran panjang dan lebar disebut hak atas tanah. $^{4}$

Menurut Klatt, menggulirkan problematika yuridis, yakni tidak dapat ditentukan apa hukumnya secara tepat (legal Indeterminacy). Legal indeterminacy ini kemungkinan disebabkan oleh berbagai hal, antara lain : kekaburan makna (vagueness), kemendua-artian makna (ambiguity), inkonsistensi (inconsistensy) dan konsep-konsep yang mendasar bertentangan atau bersaing yang disebut Gallie sebagai evaluative openness, atau konsep-konsep yang masih terbuka untuk dievaluasi. $^{5}$

Hal tersebut memunculkan banyak macam penafsiran dan pro kontra. Pro kontra terjadi baik datang dari kalangan notaris dan PPAT. Dalam pelaksanaan pendaftaran tanah yang diatur dalam UUPA Kepala Kantor Pertanahan (BPN) dibantu oleh Pejabat Pembuat Akta Tanah (PPAT). Dengan hal ini melihatkan bahwa PPAT berwenang membuat akta pertanahan. Sedangkan kewenangan tersebut juga dimiliki oleh notaris sebagaimana dalam Pasal 15 ayat 2 huruf $f$ mengenai kewenangan notaris membuat akta yang berkaitan dengan pertanahan. Penafsiran Pasal tersebut menimbulkan konflik antara Notaris, PPAT dan Badan Pertanahan Nasional (BPN). Banyak silang pendapat terhadap pasal tersebut anatara

Cetakan Ke-16, Djambatan, Jakarta, (Isnaini \& Utomo, 2019)2010, h. 72.

${ }^{4}$ Ibid, h. 18.
${ }^{5}$ Ibid 
lain seperti apakah notaris mengambil wewenang PPAT, apakah bidang pertanahan telah menjadi wewenangan notaris dan apakah notaris secara otomatis adalah pejabat yang berwenang membuat akta tanah. Namun kenyataan di lapangan, notaris tidak secara otomatis dapat menjadi Pejabat Pembuat Akta Tanah (PPAT). Pada praktik di lapangan, Notaris dapat diangkat menjadi PPAT setelah mengikuti pendidikan dan pelatihan serta dinyatakan lulus yang diselenggarakan oleh BPN.

Dari latar belakang tersebut menimbulkan permasalahan yang perlu di uraikan yakni : 1) Bagaimana kewenangan Notaris yang tidak menjabat sebagai PPAT dalam membuat akta pertanahan ?, serta, 2) Bagaimana pelaksanaan kewenangan Notaris yang tidak menjabat sebagai PPAT terhadap Pasal 15 ayat (2) huruf $f$ UUJN ?

Merujuk dari permasalahan tersebut penelitian ini bertujuan untuk

1) Untuk mengetahui kewenangan Notaris yang tidak menjabat sebagai PPAT dalam membuat akta di bidang pertanahan, serta 2) Untuk mengetahui pelaksanaan kewenangan Notaris yang tidak menjabat sebagai PPAT terhadap Pasal 15 ayat (2) huruf f UUJN.

\section{B. METODE PENELITIAN}

Jenis penelitian yang dilakukan adalah penelitian hukum normatif (Normative Legal Research), yaitu suatu penelitian yang dilakukan dengan cara mengkaji peraturan perundangundangan yang berlaku atau diterapkan terhadap suatu permasalahan tertentu. Pendekatan masalah dalam penelitian hukum ini adalah : 1) Pendekatan Perundang-undangan (Statute Approach), yaitu pendekatan dengan menelaah semua peraturan perundang- undangan yang bersangkut paut dengan permasalahan (isu hukum) yang sedang dihadapi. 2) Pendekatan Sejarah (historical approach) merupakan pendekatan yang dilakukan dalam kerangka untuk memahami filosofi aturan hukum dari waktu ke waktu, serta memahami perubahan dan perkembangan filosofi yang melandasi aturan hukum tersebut. Pendekatan Historis dalam hal ini bertitik pangkal dari sejarah jabatan Notaris memperoleh kewenangan untuk membuat akta di bidang pertanahan. dan 3) Pendekatan Konseptual (Conseptual Approach), yaitu pendekatan yang beranjak dari pandanganpandangan dan doktrin-doktrin yang berkembang didalam ilmu hukum. Pendekatan ini menjadi penting sebab pemahaman terhadap pandangan /doktrin yang berkembang dalam ilmu hukum dapat menjadi pijakan untuk membangun argumentasi hukum ketika menyelesaikan isu hukum yang dihadapi. Pandangan/doktrin akan memperjelas ide-ide dengan memberikan pengertian-pengertian hukum, konsep hukum, maupun asas hukum yang relevan dengan permasalahan.

\section{PEMBAHASAN}

\section{Kewenangan Notaris Yang Tidak Menjabat Sebagai PPAT Dalam Membuat Akta Pertanahan}

Kedudukan Notaris sebagai seorang pejabat umum merupakan suatu jabatan terhormat yang diberikan oleh Negara secara atributif melalui undang-undang kepada seseorang yang dipercayainya dan yang mengangkatnya adalah Menteri demikian berdasarkan ketentuan dalam Pasal 2 UUJN yang menyatakan "Notaris diangkat dan diberhentikan oleh Menteri".

Notaris merupakan pejabat umum yang diciptakan negara sebagai implementasi dari negara dalam memberikan pelayanan kepada rakyat yang merupakan jabatan yang istimewa, luhur, terhormat dan bermartabat karena secara khusus diatur dengan undang-undang tersendiri mengenai jabatan tersebut.(Hatta Isnaini Wahyu Utomo, 2019) Menurut Tan Thong Kie, ${ }^{6}$ masyarakat membutuhkan seseorang (figuur) yang keterangan-keterangannya dapat diandalkan, dapat dipercayai, yang tanda tangannya serta segelnya (capnya) memberi bukti kuat, seorang ahli yang tidak memihak dan penasihat yang tidak ada cacatnya (onkreukbaar atau unimpeachable), yang tutup mulut, dan membuat suatu perjanjian yang dapat melindunginya di hari-hari yang akan datang. Kalau seorang advokat membela hak-hak seseorang ketika timbul suatu kesulitan,

Notaris sebagai kepanjangan tangan dari pemerintah untuk melayani masyarakat yang membutuhkan alat bukti berupa akta otentik 
diharapkan mempunyai kualitas keilmuan yang mumpuni sehingga mampu memberikan rasa aman bagi masyarakat yang datang menghadap kepada Notaris serta mampu memberikan kepastian hukum dan perlindungan hukum. Untuk mencapai tujuan tersebut disyaratkan dalam Pasal 3 huruf e UUJN bahwa untuk dapat diangkat menjadi Notaris harus berijazah sarjana hukum dan lulusan jenjang strata dua kenotariatan. Adanya syarat tersebut diharapkan bahwa Notaris merupakan sosok yang menguasai hukum khususnya di bidang hukum privat sehingga dari akta yang dibuatnya mampu melindungi kepentingan masyarakat. ${ }^{7}$

PPAT dan produk aktanya merupakan suatu bentuk upaya dari negara untuk mewujudkan tercapainya kepastian dan perlindungan hukum untuk anggota masyarakat. ${ }^{8}$ Arti penting profesi PPAT disebabkan karena PPAT oleh Peraturan Perundang-Undangan diberi kewenangan untuk membuat alat bukti yang sempurna, dalam pengertian bahwa apa yang disebutkan dalam akta PPAT tersebut pada pokoknya dianggap benar. ${ }^{9}$ PPAT dituntut memiliki pengetahuan hukum yang luas, ketelitian, dan bertanggung jawab yang tinggi, berperilaku profesional, serta senantiasa menjunjung tinggi sumpah jabatan untuk mengabdi kepada kepentingan masyarakat dan negara guna memberikan jaminan kepastian hukum.

Pejabat Pembuat Akta Tanah adalah Pejabat Umum yang diberi kewenangan untuk membuat akta-akta tanah tertentu yang diatur dalam peraturan perundang-undangan yang bersangkutan, yaitu akta pemindahan serta pembebanan hak atas tanah dan Hak Milik Atas Satuan Rumah Susun dan akta pemberian kuasa untuk Hak Tanggungan. Berdasarkan peraturan perundang-undangan di atas yang mengatur mengenai Pejabat Pembuat Akta Tanah menunjukkan bahwa Pejabat pembuat Akta Tanah merupakan pejabat umum. Istilah pejabat umum dalam pengertian Pejabat Pembuat Akta

7 Hatta Isnaini Wahyu Utomo, "Pelaksanaan Tugas Jabatan Notaris : Bahan Diskusi Dalam Persiapan Menghadapi Ujian Kode Etik Notaris", Makalah, disampaikan pada acara Belajar Bareng Alumni, Universitas Narotama Surabaya, Februari 2018, h. 4.

${ }^{8}$ Hartanti Sulihandari \& Nisya Rifiani, Prinsip Prinsip Dasar Profesi Notaris, Cetakan Ke-1, Dunia Cerdas, Jakarta Timur, 2013, h. 3.
Tanah terdapat dihampir seluruh peraturan perundang-undangan. Yang dimaksud dengan pejabat umum adalah seorang yang diangkat oleh pemerintah dengan tugas dan kewenangan memberikan pelayanan kepada umum di bidang tertentu. ${ }^{10}$ Pendapat serupa dikemukakan pula oleh Sri Winarsi, yang menyatakan bahwa pengertian pejabat umum mempunyai karakter yuridis, yaitu selalu dalam kerangka hukum publik. Sifat publiknya tersebut dapat dilihat dari pengangkatan, pemberhentian, dan kewenangan PPAT. $^{11}$

Pasal 2 ayat (1) PP PJPPAT mengatur bahwa PPAT berwenang untuk membuat akta otentik yang digunakan sebagai alat pendaftaran peralihan hak atas tanah maupun satuan rumah susun dalam bentuk akta jual-beli, tukarmenukar, hibah, pemasukan dalam perseroan, pembagian hak bersama, pemberian hak guna bangunan, pemberian hak tanggungan dan pemberian kuasa pembebanan hak tanggungan. Dari dua macam kegiatan pendaftaran tanah, yaitu kegiatan pendaftaran tanah untuk pertama kali dan kegiatan pemeliharaan data pendaftaran tanah sebagaimana yang ditetapkan dalam PP 24/1997, kegiatan yang menjadi tugas pokok PPAT adalah kegiatan pemeliharaan data pendaftaran tanah. Terdapat perbuatan hukum yang memerlukan bantuan PPAT untuk membuat akta dalam kegiatan pemeliharaan data pendaftaran tanah. ${ }^{12}$

Tugas Pokok PPAT disebutkan dalam Pasal 2 Peraturan Jabatan PPAT yaitu melaksanakan sebagian kegiatan pendaftaran tanah dengan membuat akta sebagai bukti telah dilakukannya perbuatan hukum tertentu mengenai hak atas tanah atau Hak Milik Atas Satuan Rumah Susun, yang akan dijadikan dasar bagi pendaftaran perubahan data pendaftaran tanah yang diakibatkan oleh perbuatan hukum itu. Perbuatan hukum tersebut meliputi jual beli, tukar menukar; hibah, pemasukan ke dalam perusahaan (inbreng), pembagian hak bersama, pemberian Hak Guna Bangunan/Hak Pakai atas

${ }^{9}$ Abdul Ghofur Anshori, Lembaga Kenotariatan Indonesia Perspektif Hukum dan Etika, Cetakan Ke-4, UII Press, Yogyakarta, 2012, h. 17.

${ }^{10}$ Boedi Harsono, Op.Cit., h. 483.

11 Sri Winarsi, "Pengaturan Notaris dan PPAT Sebagai Pejabat Umum", Majalah YURIDIKA, Fakultas Hukum Universitas Airlangga, Volume 17 No.2, Surabaya, Maret 2002, h.186.

12 Boedi Harsono, Op. Cit., h. 385. 
tanah Hak Milik, pemberian Hak Tanggungan dan pemberian kuasa membebankan Hak Tanggungan. ${ }^{13}$

Dari adanya tugas pokok tersebut mengenai kewenangan PPAT diatur dalam Pasal 3 Peraturan Jabatan PPAT, yaitu :

1. untuk melaksanakan tugas pokok sebagaimana dimaksud dalam Pasal 2 Peraturan Jabatan PPAT, seorang PPAT mempunyai kewenangan membuat akta autentik mengenai semua perbuatan hukum sebagaimana dimaksud dalam Pasal 2 ayat(2) mengenai hak atas tanah dan Hak Milik Atas Satuan Rumah Susun yang terletak di dalam daerah kerjanya.

2. PPAT khusus hanya berwenang membuat akta mengenai perbuatan hukum yang disebut secara khusus dalam penunjukannya. ${ }^{14}$

Berdasarkan pasal di atas PPAT hanya berwenang untuk membuat akta-akta PPAT berdasarkan penunjukannya sebagai PPAT yang sudah sesuai dengan formasi PPAT yang telah ditetapkan oleh Menteri, sehingga apabila seorang PPAT melaksanakan kewenangannya tidak berdasarkan daerah penunjukannya sebagai PPAT maka akta yang dibuat tersebut dapat dikatakan cacat kewenangan yang akan mengakibatkan akta tersebut tidak menjadi akta otentik(Isnaini \& Utomo, 2019).

A.P. Parlindungan menyatakan bahwa tugas PPAT adalah melaksanakan suatu recording of deed conveyance, yaitu suatu perekaman pembuatan akta tanah yang meliputi mutasi hak, pengikatan jaminan dengan hak atas tanah sebagai Hak Tanggungan, mendirikan hak baru atas sebidang tanah (Hak Guna Bangunan di atas Hak Milik atau Hak Pakai di atas Hak Milik) ditambah surat kuasa memasang Hak Tanggungan. ${ }^{15}$ Pada dasarnya tugas PPAT dalam pendaftaran tanah adalah membantu Kepala Kantor Pertanahan Kabupaten/Kota dalam mewujudkan salah satu tujuan pendaftaran tanah sebagaimana ditetapkan dalam Pasal 3 PP 24/1997, yaitu untuk terwujudnya tertib administrasi pertanahan. ${ }^{16}$

PPAT dalam menjalankan tugasnya harus mandiri dan tidak memihak kepada salah satu

${ }^{13}$ Hatta Isnaini Wahyu Utomo, Op.Cit., h. 43.

${ }^{14}$ Ibid.

15 A.P. Parlindungan, Pendaftaran Tanah Di Indonesia (berdasarkan PP No. 24 Tahun 1997), Cetakan Ke-13, Mandar Maju, Bandung, 2009, h. 83. pihak. Irawan Soerodjo menyatakan bahwa jabatan PPAT merupakan suatu profesi yang mandiri, yaitu : ${ }^{17}$

a. Mempunyai fungsi sebagai pejabat umum yang berdasarkan peraturan perundangundangan mendapat kewenangan dari pemerintah melalui Menteri Negara Agraria/Kepala Badan Pertanahan Nasional untuk membuat akta peralihan hak atas tanah dan pembebanan Hak Tanggungan atas tanah yang merupakan alat bukti yang autentik.;

b. Mempunyai tugas sebagai recording of deed conveyance (perekaman dari perbuatanperbuatan) sehingga wajib mengkonstatir kehendak para pihak yang telah mencapai suatu kesepakatan di antara merek; dan

c. Mengesahkan suatu perbuatan hukum di antara para pihak yang bersubstansi mengesahkan tanda tangan pihak-pihak yang mengadakan perbuatan hukum dan menjamin kepastian tanggal penandatanganan akta.

Kehadiran UUJN telah menimbulkan pro dan kontra khususnya pada ketentuan yang berkaitan dengan pertanahan yang juga mengakibatkan banyak tafsir yang berbeda-beda. Lahirnya UUJN khususnya dalam ketentuan Pasal (15) huruf f, telah memberi kontribusi lebih bagi seorang Notaris untuk ambil peran di bidang pertanahan secara menyeluruh. Selama ini pembuatan akta yang berkaitan dengan pertanahan menjadi wewenang Pejabat Pembuat Akta Tanah (PPAT), akan bergeser kepada fungsi penuh seorang Notaris yang sebelumnya hanya pada pembuatan akta autentik mengenai aspek keperdataan di luar bidang pertanahan.

Menurut Irawan Soerodjo, kalau bertitik tolak dari pengertian Notaris sebagai pejabat umum yang berwenang membuat akta autentik, maka akta-akta tanah yang juga merupakan akta autentik jika ditinjau dari pengertian akta autentik Pasal 1816 KUHPerdata, maka kewenangan pembuatan akta-akta tersebut sebenarnya dapat dilaksanakan dihadapan Notaris, dalam hal ini Notaris juga dapat merupakan pejabat umum yang yang dapat ditunjuk khusus oleh Menteri Agraria/Kepala Badan Pertanahan Nasional (BPN) sebagai

${ }^{16}$ Urip Santoso, Pendaftaran Dan Peralihan Hak Atas Tanah, Cetakan Ke-1, Kencana Prenada Media, Jakarta, 2010, h. 34.

${ }^{17}$ Irawan Soerodjo, Kepastian Hukum Hak Atas Tanah Indonesia, Cetakan Ke-1, Arloka, Surabaya, 2013, h. 149. 
pejabat umum yang berwenang mengkonstatir suatu perjanjian dengan obyek tanah ke dalam suatu akta notariil, dengan tujuan untuk menghindari adanya spesialisasi dalam fungsi dan tugas notaris sebagai pejabat umum sebagaimana yang dimaksud dalam Pasal 1 UUJN. ${ }^{18}$

Berdasarkan Pasal 15 ayat (1) UUJN, kewenangan Notaris adalah membuat akta dengan batasan $:^{19}$

1. sepanjang menyangkut akta yang harus dibuat atau berwenang membuat akta otentik mengenai semua perbuatan, perjanjian, dan ketetapan yang diharuskan oleh aturan hukum atau dikehendaki oleh yang bersangkutan;

2. sepanjang mengenai subjek hukum untuk kepentingan siapa akta itu dibuat; dan

3. sepanjang tidak dikecualikan pada pejabat lain yang ditetapkan oleh Undang-undang;

Notaris selaku pejabat umum dilengkapi dengan kekuasaan umum, berwenang menjalankan sebagian kekuasaan Negara untuk membuat alat bukti tertulis dan otentik dalam bidang hukum perdata. Berdasarkan hal tersebut, maka jika dikaitkan dengan Pasal 15 Ayat (1) UUJN yang memberikan batasan bahwa kewenangan Notaris dalam membuat akta dibatasi dengan ketentuan "semuanya itu sepanjang pembuatan Akta itu tidak juga ditugaskan atau dikecualikan kepada pejabat lain atau orang lain yang ditetapkan oleh undangundang", maka kesimpulan yang dapat diambil yakni Notaris berwenang untuk membuat akta yang berkaitan dengan pertanahan selain 8 (delapan) akta yang merupakan kewenangan dari PPAT.

\section{Pelaksanaan Kewenangan Notaris Yang Tidak Menjabat Sebagai PPAT Terhadap Pasal 15 AYAT (2) Huruf F UUJN}

Secara historis Belanda sebagai negara asal adanya Pejabat umum di Indonesia hanya mengenal Notaris sebagai satu-satunya Pejabat Umum yang berwenang membuat akta otentik. Lain halnya di Indonesia yang mengadopsi lembaga Pejabat Umum dari Belanda justru mengenal dua macam Pejabat Umum yaitu : Notaris dan Pejabat Pembuat Akta Tanah, yang dalam hal tertentu dijabat oleh orang Notariat (sekarang Program Magister Kenotariatan) dan secara essensial keduanya mempunyai fungsi yang sama selaku Pejabat Umum yang diberikan wewenang untuk membuat akta otentik. Titik perbedaannya antara Notaris dan PPAT ini terletak pada :

a) Dasar hukum yang mengaturnya di mana Notaris diatur dalam Undang-undang Nomor 30 tahun 2004 tentang Jabatan Notaris dan mulai berlaku tanggal 26 Oktober 2004, dahulu diatur dalam Peraturan Jabatan Notaris (Staatsblad 1860:3), sedangkan Pejabat Pembuat Akta Tanah (PPAT) diatur dalam Peraturan Pemerintah Nomor 37 tahun 1998 tentang Peraturan Jabatan PPAT jo. Peraturan Pemerintah Nomor 24 tahun 2016 tentang Perubahan Atas Peraturan Jabatan PPAT Peraturan Pemerintah Nomor 37 tahun 1998 tentang Peraturan Jabatan PPAT

b) Obyek perbuatan hukumnya, dimana PPAT berwenang membuat akta otentik tentang Hak Atas Tanah dan atau Hak Milik Atas Satuan Rumah Susun, sedangkan di luar obyek tersebut menjadi wewenang Notaris.

c) Bentuk dan substansi akta PPAT yang diatur dalam PP 37 Tahun 1998 sebagian ketentuanketentuannya mengadopsi bentuk dan substansi akta notaris berdasarkan Peraturan Jabatan Notaris (Stbl 1860:3), dan pengadopsian secara parsial ini justru menimbulkan ketimpangan atau ketidakselarasan antara bentuk dan substansi akta otentik menurut Notaris dan PPAT. ${ }^{20}$

Dalam keadaan demikian hal-hal yang tidak diatur dalam Peraturan Jabatan PPAT tidak otomatis berlaku ketentuan-ketentuan dalam Peraturan Jabatan Notaris (sekarang UUJN), karena UUJN bukan merupakan lex generalis dan PP No. 37 Th. 1998 bukan merupakan lex spesialis mengingat asas lex spesialis derogat legi generalis hanya berlaku bagi UndangUndang terhadap Undang-Undang lainnya yang memiliki kedudukan sama secara hirarki.

Lingkup substansi tugas pokok PPAT dalam hubungan dengan Hukum Tanah Nasional adalah untuk melaksanakan sebagian kegiatan Pendaftaran Tanah, yang merupakan tugas pokok dari Badan Pertanahan Nasional (BPN) (Pemerintah), sedangkan tugas pokok Pejabat Umum adalah membuat Akta Otentik.

\footnotetext{
${ }^{18}$ Irawan Soerodjo, Op.Cit., h. 161-162.

${ }^{19}$ Habib Ajie, Op.Cit., h. 130-132.
}

${ }^{20}$ Ibid. 
Selanjutnya menurut ketentuan Pasal 6 ayat (2) PP 24 tahun 1997 berbunyi dalam pendaftaran tanah, Kepala Kantor Pertanahan dibantu oleh PPAT dan pejabat lain yang ditugaskan melaksanakan kegiatan-kegiatan tertentu menurut PP ini dan peraturan perundangundangan yang bersangkutan.

Selanjutnya Notaris dapat merangkap Jabatan PPAT sepanjang wilayah Jabatan PPAT masih termasuk dalam wilayah Jabatan Notaris. Pasal 6 juncto Pasal 7 juncto Pasal 9 PP 37 tahun 1998 tentang Peraturan Jabatan PPAT menegaskan antara lain yang dapat diangkat sebagai PPAT adalah lulusan program spesialis pandidikan notariat dan PPAT dapat merangkap Jabatan notaris sepanjang wilayah Jabatan PPAT termasuk dalam wilayah Jabatan Notaris. Namun dibalik perbedaan tersebut secara essensial kedua profesi hukum ini mempunyai fungsi yang sama selaku Pejabat Umum yang diberi wewenang membuat akta otentik. Keberadaan Notaris dan PPAT identik dengan Akta Otentik, yang bersumber dari Pasal 1868 Kitab UndangUndang Hukum Perdata. Pasal ini hanya merumuskan pengertian atau definisi akta otentik dan menghendaki adanya Pejabat Umum dan bentuk Akta Otentik yang diatur dalam bentuk Undang- Undang, sedangkan Kitab UndangUndang Hukum Perdata tidak mengatur siapa yang disebut Pejabat Umum dan bagaimana bentuk Akta Otentik dan untuk mengetahui tentang Pejabat Umum dan bentuk Akta Otentik harus berpijak pada UU organik yang mengatur tentang Pejabat Umum, dimana satu-satunya adalah Undang-Undang Nomor 30 tahun 2004 tentang Jabatan Notaris, yang menggantikan Peraturan Jabatan Notaris (Staatblad.1860:3). Undang-Undang Jabatan Notaris merupakan aturan lebih lanjut dari Pasal 1868 KUHPerdata, yang telah merumuskan bahwa Notaris adalah Pejabat Umum, sebagaimana telah ditegaskan dalam Pasal 1 ayat (1) UUJN yang menyatakan bahwa : Notaris adalah pejabat umum yang berwenang untuk membuat akta otentik dan wewenang lainnya sebagaimana dimaksud dalam undang-undang ini.

Kewenangan Notaris yang dimaksud dalam Pasal 1 ayat (1) UUJN, telah dirinci dalam Pasal 15 UUJN, salah satu kewenangan Notaris yang diatur dalam ketentuan tersebut adalah ditafsirkan oleh Pemerintah dalam hal ini Direktorat Jenderal Perundang-undangan, Departemen Hukum dan Hak Asasi Manusia
Republik Indonesia, sebagai bentuk peleburan tugas dan kewenangan PPAT kedalam diri Notaris, dalam arti Notaris berwenang membuat akta otentik yang obyeknya tanah, meliputi aktaakta tanah yang dimaksud dalam PP 37 tahun 1998 maupun akta-akta tanah lainnya seperti akta pengikatan jual beli yang obyeknya tanah, kuasa menjual yang obyeknya tanah, sewa menyewa yang obyeknya tanah dan sebagainya. Tugas dan lingkup kewenangan PPAT diatur dalam PP Nomor 37 tahun 1998 tentang Peraturan Jabatan PPAT yaitu membuat Akta Otentik mengenai perbuatan hukum tertentu mengenai hak atas tanah atau hak milik atas satuan rumah susun. Perbuatan-perbuatan hukum tertentu ini meliputi Jual Beli, Tukar Menukar, Hibah, Pemasukan Kedalam Perusahaan (Inbreng), Pembagian Hak Bersama, Pemberian Hak Guna Bangunan / Hak Pakai Atas Tanah Milik, Pemberian Hak Tanggungan (APHT) dan Pemberian Kuasa Membebankan Hak Tanggungan (SKMHT).

Badan Pertanahan Nasional berpendapat kewenangan Notaris yang dimaksud dalam Pasal 15 ayat (2) huruf f UU Jabatan Notaris, merupakan kewenangan Notaris untuk membuat akta-akta tanah seperti akta kuasa menjual yang obyeknya tanah, sewa-menyewa yang obyeknya tanah dan sebagainya, yang bukan termasuk kewenangan PPAT menurut PP 37 tahun 1998, kecuali Surat Kuasa Membebankan Hak Tanggungan.

Memahami arti Pasal 15 ayat (2) huruf $\mathrm{f}$ UUJN tidaklah dapat dipahami hanya dengan membaca secara harfiah kata demi kata dalam Pasal tersebut, tetapi harus dipahami sebagai suatu sistim yang tidak terpisahkan dengan PasalPasal lainnya, penjelasan Pasal-Pasal, penjelasan umum dari UUJN dan harus menempatkan UUJN sebagai bagian yang tidak terpisahkan dari hukum nasional secara keseluruhan. Pemahaman Pasal 15 ayat (2) huruf f UUJN haruslah dihubungkan dengan, Pasal 17 huruf g UUJN, yang dalam ilmu hukum dikenal dengan metode penafsiran sistematis.

Dalam ketentuan Pasal 17 huruf g UUJN berbunyi : Notaris dilarang merangkap Jabatan sebagai PPAT di luar wilayah Jabatan notaries. Secara gramatikal Pasal ini mempunyai beberapa arti atau makna yaitu:

a) Notaris boleh merangkap sebagai PPAT asal saja Jabatan PPAT yang dirangkapnya masih termasuk dalam wilayah Jabatan Notaris; 
b) Dengan adanya pengakuan jabatan rangkap ini, maka Notaris dan PPAT mempunyai kewenangan yang berbeda atau kewenangan Notaris menurut UUJN tidak sama dengan, kewenangan PPAT, kecuali ditentukan lain oleh UU lain; dan

c) Adanya peraturan perundang-undangan lain yang mengatur kewenangan PPAT.

Berdasarkan penafsiran secara sistimatis, Pasal 17 huruf g UUJN memberikan arti bahwa yang dimaksud dengan Pasal 15 ayat (2) huruf $\mathrm{f}$ UUJN adalah kewenangan notaris membuat akta-akta yang berkaitan dengan pertanahan dalam arti sempit, yaitu kewenangan untuk membuat akta-akta tanah yang tidak termasuk kewenangan PPAT berdasarkan PP 37 tahun 1998, kecuali Surat Kuasa Membebankan Hak Tanggungan (SKMHT). Peraturan Pemerintah Nomor 37 tahun 1998 tentang Peraturan Jabatan PPAT dibentuk sebagai satu kesatuan yang tidak terpisahkan dengan Pendaftaran Tanah yang diamanatkan oleh Pasal 19 Undang-Undang Pokok Agraria, yang berbunyi: untuk menjamin kepastian hukum oleh pemerintah diadakan pendaftaran tanah di seluruh wilayah Republik Indonesia yang diatur dengan Peraturan Pemerintah. Peraturan Pemerintah Nomor 37 tahun 1998 dibentuk sebagai peraturan pelaksanaan Undang-Undang Pokok Agraria (UU Nomor 5 tahun 1960) dan bukan peraturan pelaksanaan dari UU Jabatan Notaris, dan hal ini dipertegas dalam berbagai ketentuannya diantaranya yaitu: Peraturan Pemerintah Nomor 37 tahun 1998, Pasal 2, yang berbunyi: PPAT bertugas pokok melaksanakan sebagian kegiatan pendaftaran tanah dengan membuat akta sebagai bukti telah dilakukannya perbuatan hukum tertentu mengenai hak atas tanah atau Hak Milik atas Satuan Rumah Susun, yang akan dijadikan dasar bagi pendaftaran perubahan data pendaftaran tanah yang diakibatkan oleh perbuatan hukum itu.

Selanjutnya Peraturan Pemerintah Nomor 24 tahun 1997 tentang Pendaftaran Tanah, Pasal 6 ayat (2) yang berbunyi: Dalam melaksanakan pendaftaran tanah, Kepala Kantor Pertanahan dibantu oleh PPAT dan pejabat lain. Berkaitan dengan hal tersebut, tidak ada satu pasal pun ketentuan dalam Undang-Undang Jabatan Notaris yang menyatakan Peraturan Pemerintah Nomor 37 tahun 1998 dinyatakan tidak berlaku, sehingga Peraturan Jabatan PPAT ini tetap merupakan produk hukum nasional yang berlaku dan mengikat bagi setiap PPAT.

Mengenai kewenangan Notaris dalam bidang pertanahan sebagaimana tersebut dalam Pasal 15 ayat (2) huruf f UUJN, dan terjadi tarikmenarik kewenangan antara Notaris dan PPAT, di sisi yang lain, organisasi Notaris dan PPAT tidak memberikan "official statement" yang mengikat para Notaris dan PPAT atau siapa saja, tapi cenderung membiarkannya bagaikan bola liar, sehingga menimbulkan berbagai macam penafsiran mengenai ketentuan Pasal 15 ayat (2) f UUJN.

Melalui pembentukan Pejabat Umum sebagai profesi hukum yang tunggal yang berwenang membuat akta-akta otentik dapat menciptakan keseragaman bentuk akta otentik pejabat umumnya dan profesionalitasnya dan pengakuan Notaris sebagai Pejabat Umum yang tunggal ini telah dirumuskan dalam UUJN.

Melalui reposisi kedudukan PPAT dalam bentuk peleburan kelembagaan PPAT kedalam lembaga Notaris dapat terwujud :

1) Adanya kepastian hukum tentang bentuk Akta Otentik yang seragam dan dituangkan dalam bentuk UU sesuai dengan amanat Pasal 1868 KUHPerdata; dan

2) Adanya Pejabat Umum yang tunggal yang berwenang untuk membuat akta otentik tentang semua perbuatan hukum dan menghindari adanya kemajemukan Pejabat Umum seperti Pejabat Pembuat Akta Perseroan Terbatas, Pejabat Pembuat Akta Fidusia, Pejabat Pembuat Akta Yayasan, Pejabat Pembuat Akta Tanah, Pejabat Pembuat Akta Koperasi dan sebagainya. ${ }^{21}$

Memang apabila dilihat dalam wacana tersebut bagi para Notaris hal tersebut merupakan angin segar, tetapi ada baiknya sebelum direalisasikan pertama-tama kita ingat kembali tugas utama dari lembaga PPAT itu sendiri, yaitu membantu tugas Badan Pertanahan Nasional dalam sertifikasi tanah di Indonesia. Mencermati adanya perbedaan karakter yuridis antara Notaris dan PPAT, maka suatu hal yang sangat tidak mungkin dua karakter yang berbeda dijadikan satu. Menyatukan dua karakter yuridis yang berbeda hanya merupakan upaya pemaksaan yang tidak dilandasi dasar hukum yang jelas.

\footnotetext{
${ }^{21}$ Habib Adjie, Op.Cit., h. 87.
} 
Berdasarkan alasan tersebut di atas karena ada perbedaan karakter yuridis, pada akhirnya pelaksanaan kewenangan notaris berdasarkan ketentuan Pasal 15 ayat (2) huruf f UUJN, harus diberi batasan, bahwa Notaris mempunyai kewenangan di bidang pertanahan, yang bukan sepanjang kewenangan yang selama ini ada pada PPAT. Dengan demikian eksistensi lembaga Notariat dan PPAT tetap ada dengan segala kewenangannya menurut aturan hukum yang mengatur jabatan Notaris dan PPAT. Sehingga tidak perlu diributkan (kembali) substansi Pasal 15 ayat (2) huruf f UUJN tersebut. Lebih baik lembaga Notariat dan PPAT dibina sebaik-baiknya karena kedua lembaga tersebut hadir untuk kepentingan masyarakat, dan sudah menjadi bagian dari sistem hukum nasional.

Sebagai Pejabat yang berhak untuk membuat suatu akta otentik, apabila seorang Notaris mengetahui hal tersebut maka tidak diperbolehkan untuk membuatnya karena itu merupakan suatu pelanggaran. Harus diingat bahwa seorang Notaris sebagai Pejabat Umum mengemban amanat dari dua sumber, yaitu : ${ }^{22}$

a. anggota masyarakat yang menjadi klien notaris itu menghendaki agar Notaris membuatkan akta otentik bagi yang berkepentingan itu dengan secara tersirat memuat memuat kalimat amanat "penuhilah semua persyaratan formal untuk keabsahan sebagai akta otentik".

b. Amanat berupa perintah undang-undang secara tidak langsung kepada Notaris agar untuk perbuatan hukum tertentu dituangkan dan dinyatakan dengan akta otentik. Hal itu mengandung makna bahwa Notaris terikat dan berkewajiban untuk mentaati peraturan yang mensyaratkan sahnya sebagai akta otentik.

Pada hakekatnya, Notaris selaku pejabat umum, hanyalah "menkonstatir" atau "merekam" secara tertulis dan otentik dari perbuatan hukum pihak pihak yang berkepentingan. Notaris tidak berada "didalam" nya, yang melakukan perbuatan hukum itu adalah para pihak dan yang membuat berita terikat dalam dan oleh isi perjanjian adalah para pihak yang berkepentingan. Inisiatif terjadinya pembuatan akta notaris atau akta otentik itu berada pada para pihak, Notaris hanya meng- "othentisir", karenanya akta Notaris atau akta otentik, tidak menjamin bahwa para pihak "berkata benar", tetapi yang dijamin oleh akta otentik adalah para pihak "benar berkata" seperti yang termuat didalam perjanjian mereka. ${ }^{23}$

Perjanjian pengikatan jual beli tanah merupakan wewenang Notaris, sehingga apabila dikemudian hari Notaris dapat membuat akta pertanahan berdasarkan ketentuan Pasal 15 ayat (2) huruf f UUJN, maka apa yang dituangkan dalam akta perjanjian pengikatan jual beli tidak akan mengalami perubahan dengan apa yang telah dituangkan dalam oleh Notaris saat ini. Praktek sekarang ini, mayoritas Notaris adalah PPAT, sehingga tidak ada pengaruh mengenai kekuatan hukum akta yang dibuat oleh seorang notaris yang bukan PPAT maupun Notaris yang PPAT sepanjang dalam pembuatan suatu akta memenuhi syarat sebagai suatu akta otentik yang ditentukan undang-undang. Sehingga akta bersangkutan (dalam hal ini perjanjian pengikatan jual beli tanah) dapat dipergunakan sebagai alas bukti otentik oleh para pihak apabila di kemudian hari terjadi sengketa mengenai objek perjanjian. Sedangkan apabila syarat untuk menjadi akta otentik tidak dipenuhi, maka tetap saja akta tidak menjadi akta otentik melainkan menjadi akta di bawah tangan baik akta dibuat oleh Notaris maupun Notaris merangkap PPAT sebagaimana yang diwacanakan oleh Pasal 15 ayat (2) huruf f UUJN.

\section{PENUTUP}

Kewenangan Notaris dalam membuat akta otentik merupakan kewenangan yang bersifat atribusi, dimana kewenangan tersebut diberikan oleh Undang-Undang. Notaris dapat membuat akta yang berhubungan dengan pertanahan, akan tetapi dalam kewenangannya tersebut dibatasi oleh peraturan perundangundangan yang mengatur mengenai PPAT.

Keberadaan Pasal 15 ayat (2) huruf f UUJN tidak mengurangi atau menghilangkan kewenangan PPAT dalam pembuatan akta pertanahan yang sebelumnya telah menjadi kewenangan PPAT.

\section{E. DAFTAR BACAAN}

A.A. Andi Prajitno, Pengetahuan Praktis Tentang Apa dan Siapa Notaris Indonesia, Cetakan Ke-1, Putra Media Nusantara, Surabaya, 2010, h. 7.

${ }^{23}$ Ibid. h. 23. 
A.P. Parlindungan, Pendaftaran Tanah Di Indonesia (berdasarkan PP No. 24 Tahun 1997), Cetakan Ke-13, Mandar Maju, Bandung, 2009

Abdul Ghofur Anshori, Lembaga Kenotariatan Indonesia Perspektif Hukum dan Etika, Cetakan Ke-4, UII Press, Yogyakarta, 2012

Boedi Harsono, Hukum Agraria Indonesia, Sejarah Pembentukan UUPA, Isi, dan Pelaksanaannya, Cetakan Ke-16, Djambatan, Jakarta, 2010

Hatta Isnaini Wahyu Utomo. (2019). The Position of Honorary Council of Notary in Coaching Indonesian Notaries. Journal of Law, Policy and Globalization, 92. https://doi.org/10.7176/jlpg/92-12

Isnaini, H., \& Utomo, W. (2019). The existence of the notary and notarial deeds within private procedural law in the industrial revolution era 4.0. International Journal of Innovation, Creativity and Change. http://www.scopus.com/inward/record.ur 1?eid=2-s2.085079637568\&partnerID=MN8TOARS

Habib Adjie, Hukum Notaris Indonesia: Tafsir Tematik Terhadap UU No. 30 Tahun 2004 Tentang Jabatan Notaris, Cetakan Ke-6, Refika Aditama, Bandung, 2010

Hartanti Sulihandari \& Nisya Rifiani, Prinsip Prinsip Dasar Profesi Notaris, Cetakan Ke-1, Dunia Cerdas, Jakarta Timur, 2013, h. 3 .

Hatta Isnaini Wahyu Utomo, "Pelaksanaan Tugas Jabatan Notaris : Bahan Diskusi Dalam Persiapan Menghadapi Ujian Kode Etik Notaris", Makalah, disampaikan pada acara Belajar Bareng Alumni, Universitas Narotama Surabaya, Februari 2018,

Irawan Soerodjo, Kepastian Hukum Hak Atas Tanah Indonesia, Cetakan Ke-1, Arloka, Surabaya, 2013

Sri Winarsi, "Pengaturan Notaris dan PPAT Sebagai Pejabat Umum", Majalah YURIDIKA, Fakultas Hukum Universitas Airlangga, Volume 17 No.2, Surabaya, Maret 2002

Tan Thong Kie, Studi Notariat: Serba-Serbi Praktek Notaris, Cetakan Ke-7, Ichtiar Baru Van Hoeve, Jakarta, 2017
Urip Santoso, Pendaftaran Dan Peralihan Hak Atas Tanah, Cetakan Ke-1, Kencana Prenada Media, Jakarta, 2010 